\title{
Association between Socio-Economic, Psychological and Communicational Attributes of Sesame Growers with Technological Gap in the Recommended Sesame Production Technology
}

\author{
Chandrika Sharma*, N.S. Khedkar and A.K. Pande
}

College of Agriculture, Jawaharlal Nehru Krishi Vishwa Vidhyalaya, Jabalpur, (M.P.), India

\author{
*Corresponding author
}

\section{A B S T R A C T}

\section{Keywords \\ Association, Attributes, Sesame growers, Significant, Non- significant, Technological gap \\ Article Info \\ Accepted: \\ 10 June 2019 \\ Available Online: \\ 10 July 2019}

\section{Introduction}

Being 'the queen of oils' and 'poor man's substitute for ghee', sesame (Sesamum indicum L.) has vast field of applications. Sesame requires minimum seed rate, mostly grown as rainfed crop and takes only 85-90 days to get harvest. It can even be taken in zaid season when the land and farmers both are fallow after the harvest of rabi produce.

Minimum Support Price for sesame is maximum among all oilseed crops i.e. groundnut, sunflower, niger, soybean and mustard which is Rs.4600 against Rs. 4000, Rs. 3750, Rs. 3600, Rs. 2500 per respectively Anonymous (2014-15).

Not only this, it has more growth in last three year's Minimum Support Price which is $48 \%$ as compared to that of groundnut which is 40\% Anonymous(2014-15).

As it is an ancient oilseed crop, it is loosing its place in day to day meal and agricultural fields. Its productivity is minimum (375 
$\mathrm{kg} / \mathrm{ha}$ ) in the Sihora block of Jabalpur district Anonymous (2012-13).

It is also visualized that the adoption of recommended practices of sesame by the farmers is influenced by some traits of the sesame growers. So, keeping this in view the present study was designed with the objective of knowing the association between technological gap in recommended sesame production technology and the attributes of sesame growers.

\section{Materials and Methods}

Among the seven blocks of Jabalpur, Sihora block with minimum productivity $(375 \mathrm{~kg} / \mathrm{ha})$ was selected purposively. From 155 villages, a total of 10 villages having good number of sesame growers were randomly chosen from the Sihora block for the purpose. Ten sesame growers from each village, in all 100 growers were selected which constituted the sample for the study. A well-structured, pre-tested interview schedule was prepared in view of the objectives of the study and data were collected by personal interview of selected sesame growers. The association was determined with Chi-square $\chi^{2}$ test.

\section{Results and Discussion}

Table 1 depicts the association between various attributes of sesame growers like socio-economic, psychological and communicational characteristics with the technological gap which clearly reveals that the age of sesame growers, annual income and material possession were not significantly associated with the technological gap. The findings of Kapse et al., (2007) and Singh (2007) are in line with it. This clarifies that these three factors had no relation with the technological gap in sesame production technology.

Table.1 Association between technological gap and attributes of sesame growers:

\begin{tabular}{|l|l|c|c|c|c|c|}
\hline \multirow{2}{*}{$\begin{array}{c}\text { S. } \\
\text { No. }\end{array}$} & Attributes or Variables & \multicolumn{2}{|c|}{$\chi^{\mathbf{2}}$ value } & $\begin{array}{c}\text { Level of } \\
\text { significance }\end{array}$ & $\begin{array}{c}\text { Degree } \\
\text { of } \\
\text { freedom }\end{array}$ & Association \\
\cline { 3 - 6 } & Calculated & Tabulated & & & \\
\hline 1. & Age & 0.158 & 3.841 & 0.05 & 1 & Non-significant \\
\hline 2. & Education & 8.272 & 7.815 & 0.05 & 3 & Significant \\
\hline 3. & Social participation & 8.081 & 3.841 & 0.01 & 1 & Significant \\
\hline 4. & Material possession & 1.377 & 3.841 & 0.05 & 1 & Non-significant \\
\hline $\mathbf{5 .}$ & Size of land holding & 8.385 & 3.841 & 0.05 & 1 & Significant \\
\hline 6. & Land under sesame crop & 4.763 & 3.841 & 0.05 & 1 & Significant \\
\hline 7. & Annual income & 2.534 & 3.841 & 0.05 & 1 & Non-significant \\
\hline 8. & Socio-economic status & 7.502 & 3.841 & 0.05 & 1 & Significant \\
\hline 9. & Mass-media exposure & 42.402 & 6.635 & 0.01 & 1 & Significant \\
\hline 10. & Extension participation & 8.836 & 3.841 & 0.05 & 1 & Significant \\
\hline 11. & Scientific orientation & 4.294 & 3.841 & 0.05 & 1 & Significant \\
\hline 12. & Knowledge level & 37.363 & 3.841 & 0.05 & 1 & Significant \\
\hline 13. & Adoption level & 42.739 & 3.841 & 0.05 & 1 & Significant \\
\hline
\end{tabular}


Similarly, on the other hand education, size of land holding, land under sesame crop, socioeconomic status, mass-media exposure, social participation, extension participation, scientific orientation, knowledge level and adoption level were found to be significantly associated with technological gap which shows that these traits produces effect on the technological gap and are directly related to it. Other authors (Patel et al., 2010; Singh 2007; Dixit et al., 2005; Kapse et al., 2007) have reported the same.

The study leads to the conclusion that except age, annual income and material possession, all variables are crucial with respect to technological gap. Hence, in particular, education, land holding, social participation, socio-economic status, mass-media exposure, extension participation, knowledge level and adoption level are the factors which should be taken in consideration to minimize the technological gap and extensive efforts are required to uplift these factors.

\section{Acknowledgement}

Deep sense of gratitude and appreciation towards the advisory committee of the university for their guidance, constructive suggestions and generous encouragement. Extremely thankful to the Jawaharlal Nehru KrishiVishwaVidyalaya for providing necessary facilities according to the research.

\section{References}

Anonymous 2012-13. Status paper on oilseeds, Department of Agriculture and Cooperation, Govt. of India. http: /www. nmoop.gov.in

Anonymous 2014. Price Policy for Kharif Crops- The Marketing Season 2014-15. Commission for Agricultural Costs and Prices, Department of Agriculture and Cooperation, Govt. of India; (61-62).

Dixit $\mathrm{H}$ and Singh S. 2005. Impact assessment of farm women training programme with reference to Sidhi district. M.P. Madhya Journal of Extension Education. 8: 87-90.

Kapse P.S. and et al. 2007. Correlates of technological gap in recommended summer groundnut technology. International Journal of Agricultural Sciences. 3(2): 112-115.

Patel Y.V. and late Padheria M.M. 2010. Extent of technological gap and its relationship with situational, personal, socio-economic, psychological and communicational characteristics of safflower growers. Indian Research Journal of Extension Education. 10(2): 93-98.

Singh Bhagwan. 2007. Factors influencing technological gaps in adoption of mustard (Brassica juncea L.) production technology in arid zone of Rajasthan. Journal of Spices and Aromatic Crops. 16(1): 50-54.

\section{How to cite this article:}

Chandrika Sharma, N.S. Khedkar and Pande, A.K. 2019. Association between SocioEconomic, Psychological and Communicational Attributes of Sesame Growers with Technological Gap in the Recommended Sesame Production Technology. Int.J.Curr.Microbiol.App.Sci. 8(07): 1117-1119. doi: https://doi.org/10.20546/ijcmas.2019.807.132 